NBER WORKING PAPER SERIES

\title{
EDUCATION, POVERTY, POLITICAL VIOLENCE AND TERRORISM: IS THERE A CAUSAL CONNECTION?
}

\author{
Alan B. Krueger \\ Jitka Maleckova \\ Working Paper 9074 \\ http://www.nber.org/papers/w9074 \\ NATIONAL BUREAU OF ECONOMIC RESEARCH \\ 1050 Massachusetts Avenue \\ Cambridge, MA 02138 \\ July 2002
}

\begin{abstract}
We thank Claude Berrebi for excellent research assistance, Eli Hurvitz, Ayoub Mustafa, Adib Nehmeh and Zeina el Khalil for providing data, and Joshua Angrist, Fran Blau, Mia Bloom, Yinon Cohen, Jed Devaro, Guido Imbens, Christina Paxson, Jessica Stern and Elie Tamer for helpful discussions and comments. The views expressed herein are those of the authors and not necessarily those of the National Bureau of Economic Research.
\end{abstract}

(C) 2002 by Alan B. Krueger and Jitka Maleckova. All rights reserved. Short sections of text, not to exceed two paragraphs, may be quoted without explicit permission provided that full credit, including (C) notice, is given to the source. 
Education, Poverty, Political Violence and Terrorism:

Is There a Causal Connection?

Alan B. Krueger and Jitka Maleckova

NBER Working Paper No. 9074

July 2002

JEL No. J2

\begin{abstract}
The paper investigates whether there is a causal link between poverty or low education and participation in politically motivated violence and terrorist activities. After presenting a discussion of theoretical issues, we review evidence on the determinants of hate crimes. This literature finds that the occurrence of hate crimes is largely independent of economic conditions. Next we analyze data on support for attacks against Israeli targets from public opinion polls conducted in the West Bank and Gaza Strip. These polls indicate that support for violent attacks does not decrease among those with higher education and higher living standards. The core contribution of the paper is a statistical analysis of the determinants of participation in Hezbollah militant activities in Lebanon. The evidence we have assembled suggests that having a living standard above the poverty line or a secondary school or higher education is positively associated with participation in Hezbollah. We also find that Israeli Jewish settlers who attacked Palestinians in the West Bank in the early 1980s were overwhelmingly from high-paying occupations. The conclusion speculates on why economic conditions and education are largely unrelated to participation in, and support for, terrorism.
\end{abstract}

\author{
Alan B. Krueger \\ Woodrow Wilson School \\ Princeton University \\ Princeton, NJ 08544 \\ and NBER \\ akrueger@pucc.princeton.edu
}

Jitka Maleckova

Institute for Near Eastern and African Studies

Charles University in Prague

Celetna 20

10000 Praha 1, Czech Republic

jitka.maleckova@ff.cuni.cz 


\section{Introduction}

That investment in education is critical for economic growth, improved health, and social progress is beyond question. That poverty is a scourge that the international aid community and industrialized countries should work to eradicate is also beyond question. What is less clear, however, is whether poverty and low education are root causes of terrorism. This paper investigates whether there is a causal link between poverty or low education and support for terrorist activities and politically motivated violence.

In the aftermath of the tragic events of September $11^{\text {th }}$, several prominent observers - ranging from former United States Presidential candidate George McGovern to President George W. Bush, as well as academics, including Joseph Nye, Dean of the Kennedy School of Government, Laura Tyson, Dean of the London Business School, and Richard Sokolsky and Joseph McMillan of the National Defense University - have called

for increased aid and educational assistance to end terrorism. ${ }^{\square}$ Perhaps surprisingly, our review of the evidence provides little reason for optimism that a reduction in poverty or an increase in educational attainment, by themselves, would meaningfully reduce international terrorism. Any connection between poverty, education and terrorism is indirect, complicated and probably quite weak. Instead of viewing terrorism as a direct response to low market opportunities or ignorance, we suggest it is more accurately viewed as a response to political conditions and long-standing feelings (either perceived or real) of indignity and frustration that have little to do with economics.

\footnotetext{
${ }^{1}$ After refraining from drawing a connection between poverty and terrorism for a time, on March 23, 2002 President Bush announced in Monterrey, Mexico, "We fight against poverty because hope is an answer to terror." See Laura Tyson, "It's Time to Step Up the Global War on Poverty" Business Week, Dec. 3, 2001, Richard Sokolsky and Joseph McMillan, "Foreign Aid in our Own Defense," New York Times Op-ed,
} 
An understanding of the causes of terrorism is essential if an effective strategy is to be crafted to combat it. Moreover, drawing a connection between poverty and terrorism if it is not justified is potentially quite dangerous as the international aid community may lose interest in providing support to developing nations when the imminent threat of terrorism recedes, much like support for development waned in the aftermath of the Cold War. And connecting foreign aid with terrorism risks the possibility of humiliating many in less developed countries, who are implicitly told they only receive aid to prevent them from committing acts of terror. Furthermore, premising foreign aid on the threat of terrorism could create perverse incentives in which some groups are induced to engage in terrorism to increase their prospect of receiving aid. In our view, alleviating poverty is reason enough to pressure economically advanced countries to provide more aid than they are currently giving.

To make any headway investigating the determinants of terrorism, one must have a working definition of terrorism. This is a difficult task. More than 100 diplomatic or scholarly definitions exist. The types of activities by various groups considered terrorist acts differ substantially across the definitions. The term terrorism has also evolved over time. When first used in a political context during the French Revolution, the term was reserved for accusations against those who, like Robespierre, made use of violence in the name of the state. By the late $19^{\text {th }}$ Century, however, Russian and French anarchists proudly used the term terrorism to describe their violent endeavors against the state. Part of the difficulty in defining terrorism is that there are valid disputes as to which party is a legitimate government. During World War II, for example, the German occupation

February 12, 2002, and George McGovern, "The Healing in Helping the World's Poor," New York Times Op-ed, January 1, 2002. 
forces labeled members of resistance groups as terrorists. "One man's terrorist," the saying goes, "is another's freedom fighter."

There is a range of possible definitions. On the one hand, the U.S. State Department, which acknowledges that no single definition of terrorism has gained universal acceptance, seems to capture what is considered terrorism by many governments and international organizations. Since 1983, the State Department has employed the following definition for statistical and analytical purposes:

The term 'terrorism' means premeditated, politically motivated violence perpetrated against noncombatant targets by subnational groups or clandestine agents, usually intended to influence an audience.

The term 'international terrorism' means terrorism involving citizens or the territory of more than one country.

The State Department also specifies that "the term noncombatant is interpreted to include, in addition to civilians, military personnel who at the time of the incident are unarmed and/or not on duty.... We also consider as acts of terrorism attacks on military installations or on armed military personnel when a state of military hostilities does not exist at the site, such as bombings against U.S. bases in the Persian Gulf, Europe, or elsewhere." The rub, of course, is that the definition of "subnational" and "military hostilities" leaves much latitude for disagreement.

On the other hand, definitions used by scholars tend to place more emphasis on the intention of terrorists to cause fear and terror among a target audience with the aim of persuasion that transcends the harm caused to the immediate victims. Scholarly definitions often also include nation states as potential perpetrators of terrorism.

Rather than dogmatically adhere to one definition, we analyze involvement in, or support for, activities that, at least when judged by some parties, constitute terrorism. 
Nevertheless, in the incidents analyzed in our paper the line between terrorism and resistance is often blurred; indeed, in the case of Hezbollah in the 1980s we think it is fair to say that terrorism was a tactic sometimes used in resistance against an occupying force. A similar statement could be made about Palestinian militance. At the least, however, all of the cases we examine could be thought of as involving politically motivated violence. Moreover, it is reassuring that our main conclusions appear to hold across a varying set of circumstances, cultures and countries.

We do not examine state terrorism because we suspect the process underlying participation in state terrorism is quite different than the process underlying substate terrorism, and would involve a different type of analysis. We do not dispute, however, that state terrorism exists, and has at times generated substate terrorism as a response.

In the next section we provide an overview of theoretical considerations involved in the decision to participate in terrorist-type activities. As is conventional in economics, involvement in terrorism is viewed as a rational decision, depending on the benefits, costs and risks involved from engagement in terrorism compared to other activities. Not surprisingly, the standard rational choice framework does not yield an unambiguous answer to the question of whether higher income and more education would reduce participation in terrorism.

Evidence on the determinants of terrorism is just beginning to be assembled. The second section of our paper considers evidence on "hate crimes," which we argue can be viewed as a close cousin to terrorism in that the target of the offense is selected because of his or her group identity, not their individual behavior, and because the effect of both is to wreak terror in a wider audience than those directly affected. A consensus is 
emerging in the social science literature that the incidence of hate crimes, such as lynchings of African Americans or violence against Turks in Germany, bears little relation to economic conditions.

The third section considers data from a public opinion poll conducted in the West Bank and Gaza Strip by the Palestinian Center for Policy and Survey Research (PCPSR). In December 2001, Palestinians were asked whether they support attacks on Israeli civilian and military targets, and about whether they considered certain events acts of terrorism. We report breakdowns of the data by education and occupation. These results indicate that support for violence against Israeli targets is widespread in the Palestinian population, and at least as great among those with higher education and higher living standards as it is among the unemployed and illiterate.

The fourth section contains the main new contribution of our paper, a statistical analysis of the determinants of participation in Hezbollah in Lebanon. We analyze a sample of data that combines information on 129 members of Hezbollah who were killed primarily while involved in paramilitary actions in the late 1980s and early 1990s with a general population survey of similarly aged individuals in Lebanon. We find that education and poverty are statistically insignificant predictors of whether individuals become martyrs for Hezbollah. Indeed, having a standard of living above the poverty line or a secondary-school education or higher is positively associated with participation in Hezbollah. The results are consistent with the biographical evidence assembled for Palestinian suicide bombers.

The fifth section presents a summary of the backgrounds of 27 Israeli Jews who were involved in terrorist activities in the Occupied Territories in the early 1980s. These 
individuals, who planted bombs and attempted to assassinate Palestinian mayors, are remarkably well educated and drawn from well paying occupations.

In the sixth section we present an analysis of the incidence of major terrorist acts (cited in the International Encyclopedia of Terrorism) over time in Israel. Specifically, we relate the number of terrorist acts each year to the rate of economic growth in that year or in the recent past.

The data on participation and support for political violence, militance and/or terrorism that we examine are meager, often indirect, and possibly nonrepresentative. In addition, participation in terrorist activities may be highly context-specific, and we only examine terrorism, militance and politically motivated violence in a small number of settings primarily in the Middle East. Consequently, our results must be considered tentative and exploratory. Nonetheless, we are not aware of compelling evidence that points in the opposite direction from what we have found. In light of our results and the literature, we would urge intellectuals and policy makers to exercise caution in presuming that poverty and education have a direct, causal impact on terrorism.

\section{Theoretical Considerations of Participation in Terrorism}

A simple view of terrorism is that participation in terrorism is akin to participation in crime in general. Economists have a well worked out and empirically successful theory of participation in criminal activities. As emphasized by Becker (1968), individuals should choose to allocate their time between working in the legal job market or working in criminal activities in such a way that maximizes their utility. After accounting for the risk of being caught and penalized, the size of the penalty, and any stigma or moral distress associated with involvement in crime, those who receive higher 
income from criminal activities would choose involvement in crime. In this model, crime increases as one's market wage falls relative to the rewards associated with crime, and decreases if the risk of being apprehended after committing a crime or the penalty for being convicted of a crime rises.

Available evidence suggests that individuals are more likely to commit property crimes if they have lower wages or less education. ${ }^{6}$ The occurrence of violent crimes, including murders, however, is typically found to be unrelated to economic opportunities. 目

Landes (1978) and Sandler, et al. (1983) apply the economic model of crime to transnational terrorism. They focus on how an increase in penalties and law enforcement influences the incentive to partake in terrorist activities. The economic model, however, yields few concrete predictions insofar as the relationship between market opportunities and participation in terrorism is concerned because participation in terrorist acts by individuals with different characteristics depends on the probability that participation will bring about the desired political change, and the differential payoff for the various groups associated with achieving the terrorists' desired aims versus the penalties associated with failure. For example, it is possible that well educated individuals will disproportionately participate in terrorist groups if they think that they will assume leadership positions if they succeed, or if they identify more strongly with the goals of the terrorist organization than less educated individuals.

Other important considerations include the relative pay of skilled and unskilled individuals for participation in terrorist organizations and how it compares to relative pay

\footnotetext{
${ }^{2}$ See, for example, Ehrlich (1973), Freeman (1996), and Piehl (1998).

${ }^{3}$ See, for example, Piehl (1998) and Ruhm (2000).
} 
in the legal sector, and the selection of terrorists by terrorist organizations from the pool of potential applicants. Keller (2002) reported that Iraq decided to increase the payment to families of suicide bombers from $\$ 10,000$ to $\$ 25,000$ in March 2002 in the West Bank and Gaza Strip. In the month after that decision, suicide bombings increased, although it is unclear whether the connection is causal.

Even before the increase in the payment to families of suicide bombers, Nasra Hassan (2001) reported that there was an excess supply of willing suicide bombers. Between 1996 and 1999, Ms. Hassan, a relief worker for the U.N., interviewed nearly 250 militants and associates of militants involved in the Palestinian cause, including failed suicide bombers, the families of deceased bombers, and those who trained and prepared suicide bombers for their missions. ${ }^{⿴}$ One Hamas leader Ms. Hassan interviewed said, "Our biggest problem is the hordes of young men who beat on our doors, clamoring to be sent [on suicide missions]. It is difficult to select only a few." Another senior member of Hamas's al-Qassam said, "The selection process is complicated by the fact that so many wish to embark on this journey of honor. When one is selected, countless others are disappointed." Thus, the demand side is also part of the equation.

With a queue of willing participants, how do terrorist or militant groups choose their suicide bombers? A planner for Islamic Jihad explained to Ms. Hassan that his group scrutinizes the motives of a potential bomber to be sure that the individual is committed to carrying out the task. $\mathrm{A}$ high level of educational attainment is probably a signal of one's commitment to a cause and determination, as well as of one's ability to

\footnotetext{
${ }^{4}$ Ms. Hassan reported that the sponsoring terrorist organization usually gave between $\$ 3,000$ and $\$ 5,000$ to the families of suicide bombers. Apart from that payment, she reported that the typical cost of the operation was around $\$ 150$.
} 
prepare for an assignment and carry it off, so the stereotype of suicide bombers being drawn from the ranks of those who are so impoverished that they have nothing to live for may be 180 degrees off base. This interpretation is also consistent with another of Ms. Hassan's observations about suicide bombers:

None of them were uneducated, desperately poor, simple minded or depressed. Many were middle class and, unless they were fugitives, held paying jobs. More than half of them were refugees from what is now Israel. Two were the sons of millionaires.

Suicide bombers are clearly not motivated by the prospect of their own individual economic gain, although it is possible that the promise of larger payments to their families may increase the willingness of some to participate in suicide bombing missions. We suspect their primary motivation instead results from their passionate support for the ultimate aims and desires of their movement. Nassra Hassan, for example, reported, "Over and over, I heard them say, 'The Israelis humiliate us. They occupy our land, and deny our history." Eradication of poverty and universal high school education are unlikely to change these feelings. Indeed, it is even possible that those who are well off and well educated perceive such feelings more acutely.

Economic theory is unlikely to give a very convincing answer one way or the other as to whether poverty or education are important root causes of terrorism. One could construct plausible explanations for why a reduction in poverty and a rise in education might increase or decrease the incidence of terrorism. Next we turn to a broad consideration of evidence related to terrorism.

\footnotetext{
${ }^{5}$ Ms. Hassan also observed that the groups generally reject for suicide bombing missions "those who are under eighteen, who are the sole wage earners in their families, or who are married and have family responsibilities."

${ }^{6}$ Observe, for example, that well educated and high-income people are consistently more likely to vote than are less educated and poor people. If the primary payoff motivating people to join and support terrorist
} 


\section{Evidence from Hate Crimes}

Because the literature on participation in terrorism is less well developed than the literature on "hate crimes," we begin by briefly reviewing evidence on the economic determinants of hate crimes, a phenomenon that many have considered closely related to terrorism (e.g., Hamm, 1998 and Kressell, 1996). Hate crimes are commonly defined as crimes against members of religious, racial or ethnic groups because of their group membership, rather than their characteristics or actions as individuals. Hate crimes include acts of violence, as well as destruction of property, harassment and trespassing. Until recently, social scientists thought economic deprivation was a crucial determinant of hate crimes. New evidence, however, strongly challenges the empirical basis for this

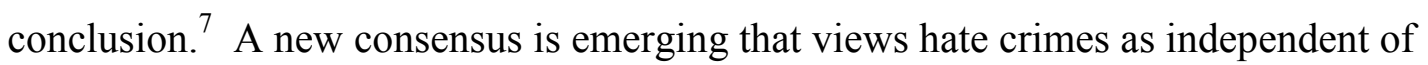
economic deprivation.

The original empirical support for the "economic deprivation hypothesis" stemmed mainly from historical evidence on anti-black lynchings in the southern part of the United States. In his 1933 classic study, The Tragedy of Lynching, Arthur Raper documented a correlation of -0.532 between the number of lynchings in a year and the value of an acre of cotton (a measure of economic conditions) in that year using annual time-series data from 1882 to 1930 . He concluded that, "periods of relative prosperity bring reduction in lynching and periods of depression cause an increase." The psychologists Carl Hovland and Robert Sears (1940) seized on this finding as support for

organizations is the potential to influence political change, then it would not be surprising if education and income have the same effect on participation in terrorism as they do on participation in voting.

${ }^{7}$ See Green, McFalls, and Smith (2001) for a good survey of the literature. 
the view that intergroup antagonism results from frustration accompanying economic contractions.

A landmark study by Green, Glaser and Rich (1998) overturns that conclusion. First, they showed that the correlation between lynchings and economic conditions vanished once secular trends in both variables were taken into account. That is, apart from the long-term tendency for the number of lynchings to decline and the economy to grow, lynchings were unrelated to year-to-year economic fluctuations. Second, when they use Simon Kuznets's measure of real per capita GNP growth (which was unavailable to Raper) as a measure of economic conditions instead of the price of cotton, they find that lynchings and economic conditions are virtually uncorrelated.

Third, and most important, Raper's sample ended just before the Great Depression. Lynchings did not rise during the Great Depression, despite the dramatic deterioration in economic conditions. When Green, Glaser and Rich extend the original sample through 1938, they find an insignificant correlation between the number of antiblack lynchings and the value of an acre of cotton, and a positive correlation between anti-black lynchings and real GNP growth. It is almost certainly the case that the inverse correlation reported between economic conditions and anti-black lynchings that launched the aggression-frustration hypothesis was spurious, a coincidence of two unrelated trends that happened to move in the opposite direction at the turn of the $20^{\text {th }}$ Century.

Moreover, the evidence of a connection between economic conditions and other types of hate crimes in contemporary data is also elusive. Green, Glaser and Rich (1998) report time-series evidence on the incidence of hate crimes against blacks, Jews, Asians and gay men and lesbians using data from New York City each month from 1987 to 
1995. They found that the incidence of these crimes was unrelated to the city's unemployment rate.

Across regions in a given year, the occurrence of hate crimes and prevalence of hate groups are also found to be unrelated to economic circumstances of the area. Jefferson and Pryor (1999), for example, examined determinants of the existence of hate groups across counties in the United States in 1997, using a list of hate groups assembled by the Southern Poverty Law Center. Specifically, they used logistic regressions to relate the characteristics of counties to the likelihood that the county was home to a chapter of a hate group. About 10 percent of the 3,100 counties in the continental United States contained one or more hate group, like the Klu Klux Klan. The existence of hate groups was unrelated to the unemployment rate, divorce rate, percent black, or gap in per capita income between whites and blacks in the county. The share of the adult population with a high school diploma or higher had a statistically significant, positive association with the probability that a hate group was located in the area. They concluded that, "economic or sociological explanations for the existence of hate groups in an area are far less important than adventitious circumstances due to history and particular conditions."

The findings for the United States do not appear to be unique. Germany experienced a rash of violence against foreigners in the early 1990's. Unemployment was high, particularly in the former East Germany. Krueger and Pischke (1997), however, found no relationship between the unemployment rate and the incidence of ethnic violence across 543 counties in Germany, once they controlled for a dummy variable indicating whether the county was located in the former East or West Germany. Likewise, average education and the average manufacturing wage in the county was 
unrelated to the amount of violence against foreigners. Within the former East Germany, those counties located furthest from the west had the highest incidence of ethnic violence. Krueger and Pischke attribute the geographic pattern to a failure of law enforcement further east, and pent up animosity that was suppressed during Communism.

To summarize, neither cyclical downturns nor longer-term regional disparities in living standards appear to be correlated with the incidence of a wide range of hate crimes. This is not proof of the absence of a causal relationship, but if there were a direct causal effect one would expect hate crimes to rise during periods of economic hardship. Rather than economic conditions, the hate crimes literature points to a breakdown in law enforcement and official sanctioning and encouragement of civil disobedience as significant causes of the occurrence of hate crimes.

\section{Evidence from Public Opinion Polls in the West Bank and Gaza Strip}

Although public opinion polls are subject to multiple interpretations, such data can provide indirect information about which segments of the population support terrorist or militant activities. Here we analyze public opinion data collected by the Palestinian Center for Policy and Survey Research (PCPSR), an independent, nonprofit institution and think tank located in Ramallah that performs policy analysis and academic research in the West Bank and Gaza Strip. We should emphasize that these results are undoubtedly highly context specific, due to the long lasting Israeli-Palestinian conflict and due to the fact that Palestinians are without a state or army and are highly dependent economically on Israel.

The PCPSR conducted a public opinion poll of 1,357 Palestinians age 18 or older in the West Bank and Gaza Strip on December 19-24, 2001. The survey, which was 
conducted by in-person interviews, covered topics including views toward the September $11^{\text {th }}$ attacks in the United States, support for an Israeli-Palestinian peace agreement, and views toward armed attacks against Israel..$^{8}$ Under trying circumstances in the midst of one of the worst periods of the Israeli-Palestinian conflict, Ayoub Mustafa of the Center kindly provided us with tabulations of key questions broken down by the educational level and occupational status of the respondents.

Tables 1 and 2 provide a summary of the results. The questions are presented in the order in which they were asked in the survey, so the reader can gauge context and order effects (although results are not available for all questions, so there are some gaps in the questions).

Several findings are evident. First, the support for armed attacks against Israeli targets by the Palestinian population is widespread (Q18). It is important to emphasize, however, the distinction between support for armed attacks expressed in a public opinion poll at a particular point in time and participation in such attacks.

Second, a majority of the Palestinian population believes that armed attacks against Israeli civilians have helped achieve Palestinian rights in a way that negotiations could not have (Q17). This finding raises obvious implications concerning the difficulty of ending the attacks, and may partially account for the opposition to a United Nations initiative to fight terrorism (see Q21). If the Palestinian public believes the attacks are efficacious, they are unlikely to cease supporting additional attacks unless their demands are met. Another question (Q19, not shown in table) asked, "To what extent do you support or oppose the position taken by President Arafat and the PA regarding the U.S.

\footnotetext{
${ }^{8}$ The questionnaire and aggregate results are available from $<$ www.pcpsr.org/survey/polls/2001/p3a.html $>$.
} 
campaign against terror?" Thirty-six percent supported or strongly supported the position of President Arafat in this case, and 50.4 percent opposed it.

Third, a majority of the Palestinian population did not consider suicide bombings, like the one that killed 21 Israeli youths at the Dolphinarium night club in Tel Aviv, terrorist events (Q22-5). Toward the end of the questionnaire, respondents were also asked whether they thought the international community considered the Dolphinarium bombing a terrorist event (Q23-5, not shown). Ninety-two percent responded yes. These results highlight differences in interpreting the meaning of the word terrorism.

Fourth, and important for our purposes, there is no evidence in these results that more highly educated individuals are less supportive of violent attacks against Israeli targets than are those who are illiterate or poorly educated. Consider, for example, the percentage of individuals who say they support or strongly support armed attacks against Israeli targets less those who say they oppose or strongly oppose such attacks. By a 68 percentage point margin those with more than a secondary school education support armed attacks against Israeli targets, while the margin is 46 points for those who are illiterate and 63 points for those with an elementary school education. A chi-square goodness-of-fit test decisively rejects the null hypothesis that responses to the question concerning support for armed attacks against Israel (Q18) are independent of educational attainment ( $\mathrm{p}$-value $=0.004)$.

A survey conducted by PCPSR in November 1994, before the current intifada, asked respondents whether they supported a dialogue between Hamas and Israel (see Www.pcpsr.org/survey/cprspolls/94/poll13a.html . Responses were reported by educational attainment. More highly educated respondents were less supportive of a 
dialogue with Israel: 53 percent of those with a BA and 40 percent of those with an MA or Ph.D. supported a dialogue, compared with 60 percent of those with a 9 years or less of schooling. (Based on other questions, it is clear that supporters of dialogue generally favored a more peaceful coexistence with Israel.)

Fifth, support for armed attacks against Israeli targets is widespread across all occupations and groups, but particularly strong among students (recall that respondents are age 18 or older) and merchants, farmers and professionals. (Only 22 respondents were farmers, and some may own farms, so we included them with merchants and professionals.) Notably, the unemployed are somewhat less likely to support armed attacks against Israeli military, and especially civilian, targets. If poverty was the wellspring of support for terrorism or politically motivated violence, one would have expected the unemployed to be more supportive of armed attacks than merchants and professionals, not less.

Sixth, notice that housewives' responses are quite similar to those of the general public. The attitudes of the housewives exhibited in the PCPSR survey are significant in part because they are likely to have substantial influence on their children's views and activities.

Seventh, the survey found that the Palestinian population doubted bin Laden's role in the September $11^{\text {th }}$ attacks on New York. A subsequent poll by the Gallup Organization of adults in nine countries in the Islamic world also found considerable skepticism toward the role of bin Laden's group in the attacks on New York and Washington. For example, 74 percent of Muslim Lebanese did not believe news reports that groups of Arabs carried out the attacks. In contrast, 65 percent of Christian Lebanese accepted the veracity of the 
news reports. Respondents in the PCPSR survey were divided on whether they defined as a "terrorist event" the "destruction of the Twin Towers in New York City by people suspected to be members of Bin Laden's organization": 41.4 percent agreed and 53.1 percent disagreed.

\section{Economic Expectations}

It is possible to use public opinion data to infer trends in economic expectations. On three occasions - in July/August 1998, September 1999, and February 2000 - PCPSR asked respondents in the West Bank and Gaza Strip the following two questions: "How would you describe your economic situation over the last three years compared to the situation today? Better, Worse, Stayed the Same, or Don't Know?" and "Are you optimistic or pessimistic regarding your economic situation over the next three years? Optimistic, Pessimistic, It will remain the same, No Opinion/Don't Know?” Tabulations of responses to these two questions, as well as the unemployment rate, which is available with more frequency, are shown in Table 3.

The survey results indicate that between 1998 and 2000 the public perceived economic conditions to be improving, and optimism for the future was rising. The downward trend in the unemployment rate is also consistent with this interpretation of economic circumstances. There is little evidence here to suggest that a deteriorating economy or falling expectations for the economy precipitated the latest intifada, which began in September 2000, although it is possible that expectations could have changed between the PCPSR's last survey and the start of the intifada.

Angrist (1995) closely examines trends in school enrollment, earnings and unemployment by level of education in a period encompassing the intifada in 1988 . He 
finds that college enrollment in the West Bank and Gaza Strip increased rapidly in the early 1980s, doubling between 1981 and 1985. Between 1982 and 1988 the number of Palestinian men in the labor force with 12 or more years of schooling doubled, while the number with 11 or fewer years of schooling increased only around 30 percent. This remarkable rise in the education of the workforce coincided with a sharp increase in the unemployment rate for college graduates relative to high school graduates in the 1980s. In addition, from 1985 to 1988 the real daily wage of college graduates fell by around 30 percent, while the real wage of those with 12 years of schooling held steady and the real wage of those with 11 or fewer years of schooling increased slightly. Angrist notes that the decline in Palestinian school enrollment in the early 1990s probably represents "a belated supply response to low returns to schooling."

Thus, the noteworthy increase in educational attainment of Palestinians in the 1980s coincided with a marked deterioration in the economic position of more highly educated Palestinians. Angrist and others speculate that the deterioration in economic opportunities for the highly educated contributed to the civil unrest that broke out in December 1987. Angrist notes, however, that the confluence of these developments could be unique to the Palestinian situation, and not a universal response to expanding educational opportunities. Importantly, the Israeli occupation of the territories and lack of an effective capital market or banking system probably prevented the labor markets in the West Bank and Gaza Strip from equilibrating, particularly in light of the fact that many Palestinians are dependent on Israel for jobs. Consequently, the link between an expansion in educational attainment, deteriorating economic conditions and protest may not generalize. Indeed, the contrasting economic environments surrounding the intifadas 
in 1988 and 2000 suggest that protest, violence and even terrorism can follow either a rising or declining economic tide.

\section{Correlates of Participation in Hezbollah Militant Activities}

The Hezbollah (or Hizb'allah, Party of God) was founded in Lebanon in 1982, following the Israeli occupation of southern Lebanon. The original goal of Hezbollah was to fight the Israeli occupation and create a Shiite state in Lebanon, modeled on Iran. The organization refrained from publicly claiming responsibility for its actions for three years after it was formed, and did not reveal its name until 1985. Hezbollah has since evolved into a complex social, political and resistance organization, and currently posts a web site in English and Arabic (www.hizbollah.org) that describes its multifaceted activities.

Hezbollah is based in three main areas in Lebanon: Beirut, the Bekaa Valley and southern Lebanon. Hezbollah has used various means to achieve its goals. In the 1980s, taking Western hostages proved successful, especially when President Reagan was willing to trade arms for hostages. In the early 1990s, Hezbolah participated in Lebanese elections with some success. Beginning in the 1980s, Hezbollah also introduced suicide attacks, first against Israeli military bases in southern Lebanon and later against Western soldiers in Beirut. Hezbollah is believed to be responsible for the suicide truck bombings of the U.S. Embassy annex in 1984, and the U.S. marines' and French paratroopers' barracks in 1983 in Beirut. The U.S. State Department and British Home Office have labeled Hezbollah as a terrorist organization.

Currently, Hezbollah supports the radical Palestinian movements, Hamas and Islamic Jihad, in their campaign against Israel. It is from Hezbollah that these 
organizations reportedly have adopted the technique of suicide bombings. It has also been reported that Hezbollah and al Qaeda have joined forces after al Qaeda was dispersed from Afghanistan.

\section{Statistical Analysis of Hezbollah Participation}

Eli Hurvitz of Tel Aviv University graciously provided us with biographical information on 129 members of Hezbollah's military wing (Al-Muqawama Al-Islamiya) who died in action from 1982 to 1994. Two-thirds of the Shahids, or martyrs, were killed between 1986 and 1988. The biographical details were extracted by Hurvitz from articles about the deceased fighters in Hezbollah's weekly newspaper, Al-Ahd. The observations in the sample may make up as many as one third of the members of Hezbollah's military wing in this period, according to Hurvitz. Hurvitz (1998) used the data to develop a profile of Hezbollah, but did not compare the Shahids to the Lebanese population from which they were drawn. We culled a data set from the biographies that included the individuals' age at death, highest level of school attended, poverty status, region of residence, and marital status.

There are at least three problems with the data for our purposes worth emphasizing. First, the deceased Hezbollah fighters were involved in a mix of activities, not all of which might be classified as terrorist attacks. An attack on a military post was the most common type of activity the individuals were engaged in when they were killed. Others died planting booby traps, or were assassinated by the Israeli Defense Forces or Lebanese forces. Three died in suicide bombing attacks.

\footnotetext{
${ }^{9}$ See Dana Priest and Douglas Farah, "Hezbollah, Al Qaeda Team Up,” Washington Post, June 30, 2002.
} 
Second, there are obvious selection bias issues. It is unclear whether the deceased Hezbollah militants who are described in the organization's newspaper are representative of Hezbollah members who engaged in terrorist and paramilitary activities. Hezbollah has a heterogeneous membership, ranging from untrained foot soldiers to well trained individuals. It is possible that the foot soldiers are over represented among the deceased. If this is the case, then our sample may under represent highly educated members from middle or upper income families.

Third, relevant information was missing for several individuals, and sometimes we were forced to indirectly infer variables from available information. For example, we inferred poverty status from available information on individuals' family background (e.g., parents' occupation) or from their own economic condition when it was reported, but this information was available for fewer than half of all cases. We tried to define poverty in a comparable way to how it was defined in the general population survey described below, but we could only do so with partial information so the data may not be perfectly comparable.

Obtaining data on the general population in Lebanon proved to be difficult as well. To compare the sample of Hezbollah fighters to the general population of Lebanon, we obtained an extract of individual-level data on a small subset of variables from the Lebanese Population and Housing Survey (PHS), 1996, conducted by the Administration Centrale de la Statistique. Specifically, we have information on the age, poverty status, and highest level of education attended of 287,204 individuals. Poverty status is defined on the basis of 11 living conditions indicators, including rooms per person, principal means of heating, water and sewerage access, car ownership, and occupation. There is no 
information in the PHS on whether respondents were Hezbollah members. But because we estimate that Hezbollah militants made up only 3 in 10,000 people in the Lebanese population (in the relevant age group), we ignore the fact that, in principle, some members of the PHS sample may have been Hezbollah members.

A strength of the PHS data is that the sample is large, and the survey covers a period close to the time frame of the Hezbollah sample. One problem with these data, however, is that we were not provided the sex of individuals in the population sample. All of the deceased Hezbollah fighters were male. Although we readily acknowledge that this is a shortcoming of the data, we suspect it does not seriously confound our results because, as best we can ascertain, educational attainment is similar for male and female youth in the relevant cohorts in Lebanon. The following text table reports school enrollment at various ages for male and female Lebanese youth in 1996, based on Figuié (1998).

$\begin{array}{lcc}\text { Age } & \text { Males } & \underline{\text { Females }} \\ 6-9 & 83.7 \% & 83.9 \% \\ 10-14 & 92.6 & 93.6 \\ 15-19 & 59.3 & 65.7 \\ 20-24 & 24.7 & 24.9 \\ 25-29 & 6.0 & 4.6\end{array}$

Family poverty status, region of residence and age are also likely to be orthogonal to sex, so including data on young women in the sample without controlling for gender is unlikely to severely bias our estimates.

Despite the limitations of both data sets, the samples provide some information on the characteristics of Hezbollah militants vis-à-vis the general population. If nothing else, this exercise provides an illustration of the type of analysis that could be done to learn more about the characteristics of individuals who participate in organizations that use terrorist techniques. 
Because the sample of 129 deceased Hezbollah fighters ranged in age from 15 to 38 , we restricted the PHS sample to the 120,796 individuals age 15 to 38 as well. Table 4 presents summary statistics for the sample of deceased Hezbollah militants and the general population of Lebanon age 15 to 38 . For each variable, only observations with nonmissing data on that variable are used to construct the table, so the sample varies across rows. (The PHS sample we were provided does not have any missing values.)

Several findings are of interest. First, notice that the poverty rate is 28 percent among the Hezbollah militants and 33 percent for the population -5 points lower for members of the Hezbollah military wing, although the gap is not statistically significant.

Second, in terms of education the Hezbollah fighters are more likely to have attended secondary school than are those in the general population, and a chi-square test indicates that the differences in the educational distributions between the Hezbollah and population samples are statistically significant. Because, even in this restricted age range, the Hezbollah members are younger, the education differences would be even greater if individuals with the same age distribution were compared.

Third, about one fifth of the Hezbollah sample was schooled in the Hezbollah education system. Hurvitz (1998) reports that virtually all of the Hezbollah militants were Shiite Muslims. Information on the religious affiliation of the Lebanese population is unavailable in the PHS. According to the 2002 Gallup Survey of Lebanon, however, about 57 percent of Lebanese are Muslims and nearly 43 percent are Christians. This also accords well with estimates in El Khoury and Panizza (2002). 
Fourth, the Hezbollah fighters tended to be in their late teens and early 20s when they died. Russell and Miller (1983) report that "the usual urban terrorist was between [age] 22 and 25 " in their sample of more than 350 terrorists from 18 different organizations. Fifth, the deceased Hezbollah fighters were more likely to reside in South Lebanon and Beirut than were members of the population. This finding is not surprising given that the south of Lebanon is a stronghold of Hezbollah, and was the area occupied by Israeli forces. Because educational attainment and living conditions are notably higher in Beirut than in the rest of Lebanon, it is important to try to control for regional differences in comparing the Hezbollah fighters to the general population.

Table 5 provides logistic estimates using the pooled sample of Hezbollah and PHS observations. ${ }^{10}$ The dependent variable equals one if the individual is a deceased Hezbollah fighter, and zero otherwise. The first two columns simply present unweighted estimates for the pooled sample of Hezbollah fighters and the PHS data set. However, this setup presents a classic problem of choice-based sampling: the Hezbollah militants were selected for inclusion in the sample on the basis of the dependent variable of the logit equation equaling one. Consequently, the sample does not constitute a random sample, and the unweighted estimates will generally be inconsistent. (See Manski and Lerner, 1977 for an exposition of choice-based sampling.) Columns 3-4 present logit models in which the observations have been weighted by the estimated relative frequencies of the groups in the population to their relative frequencies in the sample, which should yield consistent estimates.

\footnotetext{
${ }^{10}$ To maximize the sample size, the mean value of nonmissing values was assigned to observations with missing data for each variable in the Hezbollah sample. This procedure is not ideal and has some undesirable properties (e.g., data may not be missing at random and the reported standard errors do not reflect the additional variability due to the imputations), but it provides a simple way to impute missing
} 
Concentrating on the weighted estimates in columns (3) and (4), the results suggest that poverty is inversely related with the likelihood that someone becomes a Hezbollah fighter, and education is positively related with the likelihood that someone becomes a Hezbollah fighter. The former effect is statistically significant at the 0.05 level, and the latter at the 0.10 level, when the equation excludes region dummies, but both coefficients become insignificant when region is held constant in column (4). (The p-value for a joint test that poverty and education are unrelated to participation in Hezbollah in column (4) is 0.12.) According to the coefficient in column (3), a 30 percentage point increase in the poverty rate is associated with a 10 percent reduction in participation in Hezbollah. The same model implies that a 30 percentage point increase in the secondary school or higher attendance rate is associated with an 8 percent increase in participation in Hezbollah. These effects are 40 to 50 percent smaller in column (4), which adjusts for whether the individual resides in Beirut, South Lebanon or elsewhere in Lebanon.

As suggested by the means in Table 4, residents of Beirut and southern Lebanon are more likely to join Hezbollah. Also, even in the sample of 15 to 38 year olds, younger individuals are more likely to be represented in the deceased Hezbollah sample than in the population.

Although we lack data on the population sample's religious affiliation, and the Hezbollah participants were Shiite Muslims, to partially control for differences across religious groups we can restrict the sample to districts with a high proportion of Shiite Muslims. El Khoury and Panizza (2002; Table 1) provide estimates of the percent of the Lebanese population belonging to various religious groups for 26 districts in the PHS,

data. A more sophisticated technique would multiply impute missing observations along the lines proposed by Rubin (1987). 
based on voter registration from the 1996 national parliamentary elections. We limit the PHS sample to the six districts in which at least 69 percent of the population is a Shiitie Muslim and to Beirut, because 42 percent of the Hezbollah militants were from Beirut. 11 Columns (5) and (6) provide estimates for this geographic subsample. The results indicate an even larger negative effect of poverty on the propensity to join Hezbollah in this subsample. For this sample, which is arguably a more relevant one, a 30 percentage point reduction in poverty is associated with a 15 percent increase in participation in Hezbollah, based on column (6). And a 30 percentage point increase in secondary school enrollment is associated with an 8 percent increase in Hezbollah participation.

We regard these findings as suggestive but not definitive. First, data limitations prevent us from drawing strong conclusions. Second, the process of participation in Hezbollah, primarily a resistance organization, may not be representative of participation in other organizations that are more exclusively focused on terrorist activities. Nevertheless, these findings provide little support for the view that those who live in poverty or have a low level of education are disproportionately drawn to participate in terrorist activities. It would be useful if future research could conduct this type of analysis for other groups and in other contexts.

\section{Israeli Jewish Underground}

In the late 1970s and early 1980s, numerous violent attacks against Palestinians were conducted by Israeli Jews in the West Bank and Gaza Strip, led most prominently

\footnotetext{
${ }^{11}$ The six districts and percent of voters identified as Shiite Muslims are: Baalbek (69.1\%); Bent-Jbayl (86.7\%); El-Hermel (100\%); El-Nabatiyye (99.3\%); Marj'ayun (91.6\%); and Sour/Tyre (91.8\%). In Beirut, 13.6 percent of voters were Shiite Muslims and 44.9 percent were Sunni Muslims. We are grateful to Marianne El Khoury and Ugo Panizza for sharing these data with us.
} 
by the Gush Emunim (Bloc of the Faithful) group. These attacks included attempts to kill three Palestinian mayors of West Bank cities and failed attempts to blow up the Dome of the Rock Mosque, the third-holiest shrine of Islam. From 1980 to 1984, a total of 23 Palestinians were killed in attacks by the Jewish Underground, and 191 individuals were injured. The International Encyclopedia of Terrorism (1997) refers to these attacks as terrorism. In a ruling in 1985, an Israeli court convicted three Israeli settlers of murder and found others guilty of violent crimes in cases involving attacks in the West Bank.

What were the biographical backgrounds of those involved in these violent attacks by Israeli Jewish extremists? Table 6 reports the name, birth year, occupation and nature of underground activity for 27 individuals involved in the Jewish Underground in the early 1980s. We think this list is fairly complete and accurate, as the main source is a book by Haggai Segal (1988), one of the members of the Underground. It is clear that these Israeli extremists were overwhelmingly well educated and in high paying occupations. The list includes teachers, writers, university students, geographers, an engineer, a combat pilot, a chemist, and a computer programmer. As Neff (1999) observed of the three men convicted of murder, "All were highly regarded, welleducated, very religious." Although we have not statistically compared the backgrounds of the extremists to the wider Israeli population, the group of individuals listed in Table 6 certainly does not appear to be particularly underprivileged or undereducated.

\section{Time-Series Analysis of Terrorism in Israel}

A deterioration in economic conditions over time may be associated with the likelihood of terrorist incidents, even if cross-family differences in education and living conditions are unrelated with participation in terrorism. Sandler and Enders (2001) 
examine time trends in the number of various forms of transnational terrorist events, but do not relate economic conditions to the number of terrorist attacks. To begin to fill this void, we briefly examined whether real GDP growth in the West Bank and Gaza Strip was related to the number of major terrorist incidents in Israel.

The number of major terrorist incidents each year was derived from the International Encyclopedia of Terrorism. Between 1969 and 1996, there were 54 major terrorist attacks in Israel. The number of attacks ranged from 0 to 7 a year. We relate the number of attacks in a year to real GDP growth in the same year. Because the terrorist attacks are a count variable, a linear regression model is inappropriate. Consequently, we estimated a Poisson regression model. ${ }^{12}$ The estimated bivariate relationship, with standard errors shown in parentheses, is as follows:

\section{Log Number of Incidents $=0.54+2.86$ (Real GDP Growth)}

The number of terrorist attacks moved pro-cyclically, not counter-cyclically, and the positive association is statistically significant.

The relationship is sensitive to the specification and inclusion of other variables, however. For example, the number of terrorist incidents per year has trended significantly upward over this period. If we include a linear time trend, GDP Growth becomes statistically insignificant ( $p$-value $=0.30$ ), though it continues to have a positive effect. Interestingly, the time trend becomes negative if GDP growth is held constant. More importantly, if we use one-year lagged GDP growth instead of contemporaneous GDP growth in the equation, economic growth is found to have an inverse but statistically insignificant $(\mathrm{p}$-value $=0.30)$ bivariate relationship with the number of 
terrorist incidents. If we also include the linear time trend in the Poisson model, however, the negative effect of lagged GDP growth becomes statistically significant ( $\mathrm{p}$ value $=.02)$.

We interpret these results as providing mixed evidence as to whether terrorist attacks tend to increase or decrease with economic growth. Conducting this type of analysis on more countries and varying lag lengths, would be a useful exercise for future research.

\section{Conclusion}

The evidence we have assembled and reviewed suggests there is little direct connection between poverty, education and participation in terrorism and politically motivated violence. Indeed, the available evidence indicates that, compared with the relevant population, participants in Hezbollah's militant wing in the late 1980s and early 1990s were at least as likely to come from economically advantaged families and have a relatively high level of education as they were to come from impoverished families without educational opportunities. We should caution, however, that the evidence we have considered is tentative due to data limitations. In addition, our focus has been primarily on the Middle East, so our conclusions may not generalize to other regions or circumstances.

Nevertheless, less quantitative studies of participants in a variety of forms of terrorism in several different settings have reached a conclusion similar to ours. We are particularly struck by Russell and Miller's (1983) work in this regard. To derive a profile of terrorists, they assembled demographic information on more than 350 individuals engaged in terrorist activities in Latin America, Europe, Asia and the Middle East from

\footnotetext{
${ }^{12}$ Results are similar if we estimate a Negative Binomial model.
} 
1966 to 1976 based on newspaper reports. Their sample consisted of individuals from 18 revolutionary groups known to engage in urban terrorism, including the Red Army in Japan, Baader-Meinhof Gang in Germany, Irish Republican Army in Northern Ireland, Red Brigades in Italy and People's Liberation Army in Turkey. Russell and Miller found that, “... the vast majority of those individuals involved in terrorist activities as cadres or leaders is quite well educated. In fact, approximately two-thirds of those identified terrorists are persons with some university training, university graduates or postgraduate students." They also report that more than two-thirds of arrested terrorists "came from the middle or upper classes in their respective nations or areas."

Taylor (1988) likewise concludes from his survey of the literature that, "Neither social background, educational opportunity or attainment seem to be particularly associated with terrorism." Similarly, we show that members of the Israeli Jewish Underground who terrorized Palestinian civilians in the late 1970s and early 1980s were overwhelmingly well educated and in highly regarded occupations. Although other research has not systematically compared the backgrounds of those involved in terrorism to that of the general population, these findings suggest that most terrorists do not tend to have underprivileged backgrounds, and that this conclusion is not limited to Hezbollah.

While economic deprivation may not be associated with participation in terrorism and politically motivated violence at the individual level, it may nonetheless matter at the national level. For example, if a country is impoverished, a minority of the relatively well off in that country may turn to terrorism to seek to improve conditions of their countrymen. One might question, however, whether the end goal of many terrorist organizations is to install a political regime that is likely to reduce poverty. In addition, 
there are well documented cases of terrorism in economically advanced countries (e.g., Ireland, Spain, Italy), so it is far from clear that poverty at a national level is associated with support for terrorism. Nevertheless, this question can only be addressed by crosscountry analyses.

In addition, poverty may indirectly affect terrorism through the apparent connection between economic conditions and the proclivity for countries to undergo civil wars. Fearon and Laitin (2001) find that GDP per capita is inversely related to the onset of civil war, and Collier and Hoeffler (2000) find that the growth rate of GDP per capita and male secondary school enrollment rate are inversely related to the incidence of civil war. Lebanon, Afghanistan and the Sudan are high-profile examples of countries where civil war provided a hospitable environment for international terrorists to operate. There are other situations, however, where countries undergoing a civil war did not provide a breeding ground for international terrorism, so it is unclear how much one should extrapolate from the relationship between economic development and civil war. And terrorism has arisen in many countries that were not undergoing a civil war. Before too much is inferred about terrorism from the relationship between civil war and poverty, we think it would be useful for future research to directly examine the relationship between terrorist incidents and GDP at the national level, using similar cross-country analyses to those used in the literature on civil wars.

Enough evidence is accumulating that it is fruitful to begin to conjecture why participation in terrorism and political violence is apparently unrelated, or positively related, to individuals' income and education. The standard economic model of crime suggests that those with the lowest value of time should engage in criminal activity. But 
we would hypothesize that in most cases terrorism is less like property crime and more like a violent form of political engagement. More educated people from privileged backgrounds are more likely to participate in politics, probably in part because political involvement requires some minimum level of interest, expertise, commitment to issues and effort, all of which are more likely if people are educated and wealthy enough to concern themselves with more than mere economic subsistence. These factors could outweigh the effect of opportunity cost on individuals' decisions to become involved in terrorism.

The demand side for terrorists must be considered as well as the supply side. Terrorist organizations may prefer highly educated individuals over less educated ones, even for homicide suicide bomb attacks. In addition, educated, middle or upper class individuals are better suited to carry out acts of international terrorism than are impoverished illiterates because the terrorists must fit into a foreign environment to be successful. This consideration suggests that terrorists who threaten economically developed countries will disproportionately be drawn from the ranks of the relatively well off and highly educated.

On the whole, we conclude that there is little reason to be optimistic that a reduction in poverty or increase in educational attainment will lead to a meaningful reduction in the amount of international terrorism, without other changes. Stern (2000) observes that many madrasahs, or religious schools, in Pakistan are funded by wealthy industrialists, and that these schools deliberately educate students to become foot soldiers and elite operatives in various extremist movements around the world. She further reports that, "Most madrasahs offer only religious instruction, ignoring math, science, and other 
secular subjects important for functioning in modern society." These observations suggest that, to use education as part of a strategy to reduce terrorism, the international community should not limit itself to increasing years of schooling but should consider the content of education. 


\section{References}

Angrist, Joshua. "The Economic Retrusn to Schooling in the West Bank and Gaza Strip," American Economic Review 85(5), December 1995, pp. 1065-87.

Becker, Gary S. 1968. "Crime and Punishment: An Economic Approach," The Journal of Political Economy, 76(2), Mar. - Apr., 1968, pp. 169-217.

Black, Ian and Benny Morris. 1991. Israel's Secret Wars: The Untold History of Israeli Intelligence. London : Hamish Hamilton.

Collier, Paul and Anne Hoeffler, "Greed and Grievance in Civil War," World Bank, Policy Research Working Paper 2355.

Ehrlich, Isaac. 1973. "Participation in Illegitimate Activities: A Theoretical and Empirical Investigation." The Journal of Political Economy, May 1973, 81(3), pp. 521565.

El Khoury, Marianne and Ugo Panizza. 2002. "Social Mobility and Religion: Evidence from Lebanon,” Mimeo., Inter-American Development Bank, Washington, DC.

Fearon, James and David Laitin. 2001. "Ethnicity, Insurgency, and Civil War," Mimeo., Stanford University,.

Figuié, Gérard. Le point sur le Liban 1998, Anthologie, Beyrouth (Maisonneuve \& Larose) 1998.

Freeman, Richard. 1996. "Why Do So Many Young American Men Commit Crimes and What Might We Do About It?" Journal of Economic Perspectives 10 (1), Winter 1996, pp. 25-42.

Friedman, Robert. 1992. Zealots for Zion : Inside Israel's West Bank Settlement Movement, New York : Random House.

Green, Donald P., Jack Glaser, and A. Rich. 1998. "From lynching to gay-bashing: The elusive connection between economic conditions and hate crime," Journal of Personality and Social Psychology, 75: 82-92.

Green, Donald P., Laurence H. McFalls, and Jennifer K. Smith. 2001. "Hate Crime: An Emergent Research Agenda," Annual Review of Sociology. 27:479-504.

Hamm, Mark S. 1998. "Terrorism, Hate Crime, and Antigovernment Violence: A Review of the Research," in Harvey W. Kushner, ed., The Future of Terrorism: Violence in the New Millenium, London: SAGE, pp. 59-96. 
Hassan, Nasra. 2001. “An Arsenal of Believers," The New Yorker, November 19, pp. $36-41$.

Hovland, C. and R. Sears. 1940. "Minor Studies of Aggression: Correlation of Lynchings with Economic Indices," Journal of Psychology 9, pp. 301-10.

Hurvitz, Eli. 1998. The Military Wing of Hizballah: A Social Profile, A Masters Thesis submitted to the School of History, Tel Aviv University, and published by the Moshe Dayan Centre for Middle Eastern Studies, Tel Aviv University < www.dayan.org/ frameres.htm>.

International Encyclopedia of Terrorism, Chicago and London: Fitzroy Dearborn Publishers, 1997.

Jefferson, Philip, and Frederic L. Pryor. 1999. "On the Geography of Hate," Economics Letters, Vol. 65, No. 3, December 1999, pp. 389-395.

Keller, Bill. 2002. "Springtime for Saddam," The New York Times, April 6, p. A15.

Kressel, Neil J. 1996. Mass Hate: The Global Rise of Genocide and Terror, New York: Plenum Press.

Krueger, Alan and Jörn-Steffen Pischke. 1997. "A Statistical Analysis of Crime Against Foreigners in Unified Germany," Journal of Human Resources, Winter 1997, vol. 32, no. 1, pp. 182-209.

Landes, William. “An Economic Study of US Aircraft Hijackings, 1961-1976,” Journal of Law and Economics 21(1), pp. 1-31.

Manski, Charles and Steven Lerner. "The Estimation of Choice Probabilities from Choice Base Samples," Econometrica 45 (8), November 1977, pp. 1977-88.

Neff, Donald. 1999. "Jewish Terrorists Try to Assassinate Three Palestinian Mayors," Washington Report on Middle East Affairs, June, pp. 87-88.

Raper, Arthur. 1969. The Tragedy of Lynching, Montclair, NJ: Patterson Smith reprint series in criminology, law enforcement, and social problems. Publication no. 25.

Originally published 1933.

Rubin, Donald. 1987. Multiple Imputation for Nonresponse in Surveys, New York: John Wiley.

Ruhm, Christopher. 2000. “Are Recessions Good for Your Health?” Quarterly Journal of Economics, 115 (2), May, pp. 617-50.

Russell, Charles and Bowman Miller. 1983. "Profile of a Terrorist," reprinted in Perspectives on Terrorism, Wilmington, Delaware: Scholarly Resources Inc., pp. 45-60. 
Sandler, Todd, John T. Tschirhart, and Jon Cauley, "A Theoretical Analysis of Transnational Terrorism," The American Political Science Review, Vol. 77, No. 1. (Mar., 1983), pp. 36-54.

Sandler, Todd and Walter Enders. 2001. "An Economic Perspective on Transnational Terrorism,” Mimeo., University of Southern California, December.

Segal, Haggai. 1988. Dear Brothers - The West Bank Jewish Underground, New York : Beit-Shamai Publications, Inc.

Stern, Jessica. 2000. "Pakistan's Jihad Culture," Foreign Affairs, November/December. Taylor, Maxwell. The Terrorist. London: Brassey’s Defence Publishers, 1988. 
Table 1: Results of December 19-24, 2001 PCPSR Poll of West Bank and Gaza Strip, by Occcupation and Employment Status

Question

Q15. Do you believe that the bin Laden group is the one that

hijacked the American planes and destroyed the Twin Towers in New York on 11 September? Yes or Definitely Yes
No or Definitely No No Opinion

Q16. In your opinion, are there any circumstances under which you would justify the use of terrorism to achieve political goals?

Yes or Definitely Yes No or Definitely No No Opinion

Q17. Do you believe that armed attacks against Israeli civilians inside Israel so far have achieved Palestinian rights in a way that negotiations could not?

Yes or Definitely Yes No or Definitely No No Opinion
Laborer,

Craftsman \&

$\underline{\text { Student }}$

Employee

$25.6 \%$

$53.8 \%$

$20.5 \%$

$14.4 \%$

$63.0 \%$

$22.6 \%$

$16.0 \%$

$56.6 \%$

$27.4 \%$

$16.7 \%$

$68.3 \%$

$15.0 \%$

$12.3 \%$

$64.5 \%$

$23.2 \%$
$41.0 \%$

$49.6 \%$

$9.4 \%$

$36.0 \%$

$50.6 \%$

$13.4 \%$

$43.3 \%$

$48.3 \%$

$8.3 \%$

$38.4 \%$

$54.3 \%$

$7.2 \%$

$66.7 \%$
$31.6 \%$

$1.7 \%$

$58.2 \%$
$37.2 \%$

$4.6 \%$
$64.2 \%$

$29.2 \%$

$6.7 \%$
$63.8 \%$

$36.2 \%$ 
Laborer,

Craftsman \&

Employee

$9.4 \%$

$0.9 \%$

$80.8 \%$
$16.0 \%$

$3.1 \%$

$82.0 \%$

$15.7 \%$
$2.3 \%$

$10.0 \%$

$3.3 \%$

$73.9 \%$

Oppose or
No Opinion

Q21. Would you support or oppose a UN international initiative to fight terrorism ?

Q22-5.To what extent do you agree or disagree to define the following event as a terrorist event: "The killing of 21 Israeli youths by a Palestinian who exploded himself at the

Dolphinarium night club in Tel Aviv"

\section{Agree or Strongly Agree}

Disagree or Strongly Disagree

$12.0 \%$

$87.2 \%$

$0.9 \%$
$14.4 \%$
$81.9 \%$
$3.7 \%$

$34.9 \%$

$60.9 \%$

$27.9 \%$

$63.9 \%$

$8.2 \%$

$35.0 \%$

$60.0 \%$

$5.0 \%$

$33.3 \%$

$63.8 \%$

$2.9 \%$

Q28. Concerning armed attacks against Israeli soldiers in the West Bank and the Gaza Strip,

I....

$\begin{array}{lr}\text { Support or Strongly Support } & 95.7 \% \\ \text { Oppose or Strongly Oppose } & 3.4 \% \\ \text { No Opinion } & 0.9 \%\end{array}$
$93.4 \%$
$5.0 \%$
$1.6 \%$
$91.3 \%$
$7.9 \%$
$0.9 \%$

$94.2 \%$

$4.2 \%$

$89.9 \%$

$0.9 \%$

$1.7 \%$

Notes: Sample size is 117 for students, 381 for laborers, craftsment and employees, 562 for housewives, 120 for merchants, farmers and professionals, and 138 for unemployed. Percentages may not add up to 100 because of rounding. 
Table 2: Results of December 19-24, 2001 PCPSR Poll of West Bank and Gaza Strip, by Educational Attainment

Level of Schooling:

\section{Question}

Q15. Do you believe that the bin Laden group is the one that hijacked the American planes and destroyed the Twin Towers in New York on 11 September?

\section{No or Definitely No}

Definitely Yes

No Opinion

Q16. In your opinion, are there any circumstances under which you would justify the use of terrorism to achieve political goals?

Yes or Definitely Yes No or Definitely No

No Opinion

$32.3 \%$
$45.3 \%$

$22.4 \%$

$37.5 \%$
$53.4 \%$

$53.4 \%$

$36.9 \%$

$55.3 \%$

$7.8 \%$

$39.4 \%$

$51.4 \%$

$9.2 \%$

$36.4 \%$

$56.7 \%$

$6.9 \%$

Q17. Do you believe that armed attacks against Israeli civilians inside Israel so far have achieved Palestinian rights in a way that negotiations could not?

\author{
Yes or Definitely Yes \\ No or Definitely No \\ No Opinion
}

$\begin{array}{rrrrr}56.8 \% & 63.3 \% & 64.8 \% & 63.3 \% & 59.9 \% \\ 36.4 \% & 33.1 \% & 32.9 \% & 34.2 \% & 37.4 \% \\ 6.8 \% & 3.6 \% & 2.3 \% & 2.4 \% & 2.8 \%\end{array}$


Table 2 -- Continued

\section{Question}

Q18. Concerning armed attacks against Israeli targets, I....

Support or Strongly Support Oppose or Strongly Oppose No Opinion
Illiterate

Elementary

\section{Level of Schooling:}

\section{Middle Secondary Post-Secondary}

$\begin{array}{rrrrr}72.2 \% & 80.5 \% & 82.1 \% & 86.1 \% & 81.5 \% \\ 25.9 \% & 17.5 \% & 15.3 \% & 12.0 \% & 13.9 \% \\ 1.9 \% & 2.0 \% & 2.6 \% & 1.9 \% & 4.6 \%\end{array}$

Q21. Would you support or oppose a UN international initiative to fight terrorism?

\section{Support or Strongly Support Oppose or Strongly Oppose \\ No Opinion}

Agree or Strongly Agree

Disagree or Strongly Disagree

No Opinion

Q22-5 To what extent do you agree or disagree to define the following event as a terrorist event: "The killing of 21 Israeli youths by a Palestinian who exploded himself at the Dolphinarium night club in Tel Aviv"

Education Distribution 
Table 3: PCSR Surveys on Economic Conditions in the West Bank and Gaza Strip

\begin{tabular}{|c|c|c|c|c|c|c|}
\hline Date & & $\begin{array}{l}\text { Unemployment } \\
\text { Rate }\end{array}$ & $\begin{array}{l}\text { Economic } \\
\text { situation } \\
\text { better over } \\
\text { last } 3 \text { years }\end{array}$ & $\begin{array}{l}\text { Economic } \\
\text { situation } \\
\text { worse over } \\
\text { last } 3 \text { years }\end{array}$ & $\begin{array}{l}\text { Optimistic } \\
\text { about } \\
\text { economy } \\
\text { Next } 3 \text { years }\end{array}$ & $\begin{array}{l}\text { Pessimistic } \\
\text { about } \\
\text { economy } \\
\text { next } 3 \text { years }\end{array}$ \\
\hline Mar & 1995 & $38 \%$ & & & & \\
\hline Mar & 1996 & 49 & & & & \\
\hline Nov & 1997 & 27 & & & & \\
\hline Jul/Aug & 1998 & 26 & $37.5 \%$ & $31.2 \%$ & $50.8 \%$ & $29.2 \%$ \\
\hline Oct & 1998 & 29 & & & & \\
\hline Nov & 1998 & 24 & & & & \\
\hline Jan & 1999 & 25 & & & & \\
\hline April & 1999 & 20 & & & & \\
\hline June & 1999 & 20 & & & & \\
\hline July & 1999 & 18 & & & & \\
\hline Sept & 1999 & 23 & 39.2 & 27.6 & 50.4 & 27.5 \\
\hline Oct & 1999 & 17 & & & & \\
\hline Dec & 1999 & 19 & & & & \\
\hline Jan & 2000 & 23 & & & & \\
\hline Feb & 2000 & 19 & 43.3 & 24.6 & 55.8 & 27.2 \\
\hline Mar/Apr & 2000 & 17 & & & & \\
\hline Dec & 2001 & 21 & & & & \\
\hline
\end{tabular}

Source: PCPSR polls conducted at various times. Poll results are available from www.pcpsr.org/survey/cprspolls/index.html. 
Table 4: Characteristics of Hezbollah Militants (Shahid) and Lebanese Population of Similar Age

\begin{tabular}{|c|c|c|c|}
\hline$\underline{\text { Characteristic }}$ & $\begin{array}{l}\text { Deceased } \\
\text { Hezbollah } \\
\text { Militants }\end{array}$ & $\begin{array}{l}\text { Lebanese } \\
\text { Population } \\
\text { Age 15-38 } \\
\end{array}$ & \\
\hline$\leq$ Poverty & $28 \%$ & $33 \%$ & $p$-value for chi-sq test $=0.489$ \\
\hline \multicolumn{4}{|l|}{ Education } \\
\hline Illiterate & $0 \%$ & $6 \%$ & \\
\hline Read and write & $22 \%$ & $7 \%$ & \\
\hline Primary & $17 \%$ & $23 \%$ & \\
\hline Preparatory & $14 \%$ & $26 \%$ & \\
\hline Secondary & $33 \%$ & $23 \%$ & \\
\hline University & $13 \%$ & $14 \%$ & \\
\hline High Studies & $1 \%$ & $1 \%$ & $p$-value for chi-sq test $=0.000$ \\
\hline \multicolumn{4}{|l|}{ Age } \\
\hline $\begin{array}{l}\text { Mean } \\
\text { [std. dev.] }\end{array}$ & $\begin{array}{l}22.17 \\
(3.99)\end{array}$ & $\begin{array}{l}25.57 \\
(6.78)\end{array}$ & \\
\hline $15-17$ & $2 \%$ & $15 \%$ & \\
\hline $18-20$ & $41 \%$ & $14 \%$ & \\
\hline $21-25$ & $42 \%$ & $23 \%$ & \\
\hline $26-30$ & $10 \%$ & $20 \%$ & \\
\hline $31-38$ & $5 \%$ & $28 \%$ & $p$-value for chi-sq test $=0.000$ \\
\hline $\begin{array}{l}\text { Hezbollah } \\
\text { Education } \\
\text { System }\end{array}$ & $21 \%$ & NA & \\
\hline \multicolumn{4}{|l|}{$\underline{\text { Region of Residence }}$} \\
\hline Beirut & $42 \%$ & $13 \%$ & \\
\hline Mount Lebanon & $0 \%$ & $36 \%$ & \\
\hline Bekaa & $26 \%$ & $13 \%$ & \\
\hline Nabatieh & $2 \%$ & $6 \%$ & \\
\hline South & $30 \%$ & $10 \%$ & \\
\hline North & $0 \%$ & $22 \%$ & $p$-value for chi-sq test $=0.000$ \\
\hline \multicolumn{4}{|l|}{ Marrital Status } \\
\hline Divorced & $1 \%$ & NA & \\
\hline Engaged & $5 \%$ & NA & \\
\hline Married & $39 \%$ & NA & \\
\hline Single & $55 \%$ & NA & \\
\hline $\begin{array}{l}\text { Notes: Sample size } \\
\text { for Hezbollah is } 50 \mathrm{f} \\
\text { death, } 129 \text { for educa } \\
75 \text { for marital status } \\
\text { that the characterist }\end{array}$ & $\begin{array}{l}\text { ebanese po } \\
\text { overty status } \\
\text { in Hezbollal } \\
\text { ii-square tes }\end{array}$ & $\begin{array}{l}\text { ample is } 120, \\
\text { ucation, } 81 \mathrm{f} \\
116 \text { for regio } \\
\text { a test of the } \\
\text { lah status. }\end{array}$ & $\begin{array}{l}\text { Sample size } \\
\text { e (measured at } \\
\text { esidence, and } \\
\text { ypothesis }\end{array}$ \\
\hline
\end{tabular}


Table 5: Logistic Estimates of Participation in Hezbollah Dependent Variable is 1 if Individual is a Deceased Hezbollah Militant, and 0 Otherwise Standard errors shown in parentheses

\section{All of Lebanon:}

\section{Unweighted Estimates Weighted Estimates}

\author{
(1)
}

\begin{tabular}{lllllll} 
Intercept & -4.886 & -5.910 & -5.965 & -6.991 & -4.658 & -5.009 \\
& $(0.365)$ & $(0.391)$ & $(0.230)$ & $(0.255)$ & $(0.232)$ & $(0.261)$ \\
Attended Secondary & 0.281 & 0.171 & 0.281 & 0.170 & 0.220 & 0.279 \\
School or Higher (1=yes) & $(0.191)$ & $(0.193)$ & $(0.159)$ & $(0.164)$ & $(0.159)$ & $(0.167)$ \\
& & & & & & \\
Poverty (1=yes) & -0.335 & -0.167 & -0.335 & -0.167 & -0.467 & -0.500 \\
& $(0.221)$ & $(0.223)$ & $(0.158)$ & $(0.162)$ & $(0.159)$ & $(0.166)$ \\
Age & -0.083 & -0.083 & -0.083 & -0.083 & -0.083 & -0.082 \\
& $(0.015)$ & $(0.015)$ & $(0.008)$ & $(0.008)$ & $(0.008)$ & $(0.008)$ \\
Beirut (1=yes) & --- & 2.199 & --- & 2.200 & -- & 0.168 \\
& & $(0.219)$ & & $(0.209)$ & & $(0.222)$ \\
South Lebanon & & & & & & \\
(1=yes) & --- & 2.187 & --- & 2.187 & -- & 1.091 \\
Pseudo R-Square & & $(0.232)$ & & $(0.221)$ & & $(0.221)$ \\
Sample Size & 0.020 & 0.091 & 0.018 & 0.080 & 0.021 & 0.033 \\
\hline
\end{tabular}

Heavily Shiite Regions: Weighted Estimates

(5)

Notes: Sample pools together observations on 129 deceased Hezbollah fighters and the general Lebanese population from 1996 PHS. Weights used in columns (3) and (4) are the relative share of Hezbollah militants in the population to their share in the sample and relative share of PHS respondents in the sample to their share in the population. Weight is 0.273 for Hezbollah sample and .093 for PHS sample. 
Table 6: Characteristics of Israeli Jewish Underground Terrorists in Early 1980s

$\begin{array}{lll}\text { Name } & \begin{array}{ll}\text { Birth } \\ \text { Katriel Avinoam }\end{array} & \begin{array}{l}\text { Occupation } \\ \text { Army officer }\end{array} \\ \text { Dan Be'eri } & 1945 & \begin{array}{l}\text { Established an } \\ \text { elemetary school in } \\ \text { Kiryat Arba, founder } \\ \text { of the Barkai } \\ \text { educational method } \\ \text { Geography and } \\ \text { history expert }\end{array} \\ \text { Haim Ben-David } & 1952 & \end{array}$

Yeshua Ben-Shushan

Yehuda Cohen

Yossi Edri

Yehuda Etzion

Yitzhak Ganiram (Akaleh)

Aaron (Roni) Gilo

Benzion (Bentz)

Heineman

Boaz Heineman

\section{Year of}

$>1965$ Army officer

$1946 \quad N A$

NA Yeshiva student

NA Electrician

1951 Farmer and writer

1945 Teacher and special education teacher for learning disabled youth

NA Army captain

1936

Religious scholar and farmer

The owner of a farm and carpentry shop

\section{Underground Activity}

Related to the conspiracy attempt to blow up the Dome of the Rock Mosque 1980.

Related to the conspiracy attempt to blow up the Dome of the Rock Mosque, 1980 (left the group in 1982).

Related to the conspiracy attempt to blow up the dome of the rock mosque 1980-82, and participated in the attack on the National Guidance Committee 1980.

Instigated the conspiracy attempt to blow up the Dome of the Rock Mosque 1980.

Carried out the reconnaissance on the Temple Mount.

Participated in the acquisition of the clocks used in the attempt to blow up Arab buses (April 27, 1984).

Prime mover of the Dome of the Rock conspiracy and key figure in the attack on the mayors.

Participated in the attack on the mayors, offered limited assistance in the Dome of the Rock conspiracy. Let the perpatrators of the Islamic College killings use his car.

Not member of the Underground. But used his military position to aid those involved in the attack on the mayors.

Helped carry out the technical preparations of several underground operations.

Prepared explosives for the underground. 
Table 6 -- Continued

Yaakov Heineman

Shlomo Liviatan

Menachem Livni

Uri Meier

Natan Natanson

Menachem Neuberger

Barak Nir

Shaul Nir

Yitzchak Novik

Gilad Peli

Era Rappaport

Hagai Segal

Uzi Sharbaf

Yosef Tzuria

Noam Yinon

Moshe Zar
1948

Air force combat pilot and a farmer.

NA Officer in the Judeans Samaria Army headquarters

1950 Engineer

NA Farmer

$1957 \quad$ NA

1965 Yeshiva student

NA Teacher

1954 Engineer

1948 Chemist, farmer

NA Farmer and Israel geography expert.

$1948 \quad N A$

1957 Reporter and university student

1960 Physical education teacher

1959 Computer programmer

1957 Farmer

1937 Land dealer
Played a limited role in the conspiracy attempt to blow up the Dome of the Rock Mosque, 1980.

Played a limited role in the attack of the mayors.

Participated in planning all operations associated with the underground.

Participated in the aborted attack on Bethlehem's Dr. Natshe.

Involved in the attack on the mayors.

Participated in the intelligence gathering stage of the attack on the mayors.

Participated in the attack on the Islamic College and in the attempt to sabotage the Arab buses.

Involved in the Islamic College killings and initiated the attempt to sabotage the Arab buses

Participated in the attack on the mayors.

Helped in the attack on the mayors; helped in the Dome of the Rock conspiracy.

Participated in the attack on the mayors.

Participated in the attack on the mayors.

Involved in the Islamic College killings and initiated the attempt to sabotage the Arab buses.

Related to the conspiracy attempt to blow up the Dome of the Rock Mosque.

Convicted of supplying explosives to Livni and Shaul.

Was the driver in the attack on the mayors.

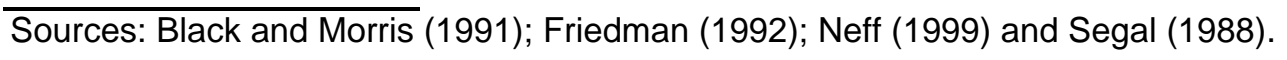

